\title{
ANTIGEN UPTAKE IN GILL EPITHELIUM OF RAINBOW TROUT AND AYU DURING BATH-VACCINATION
}

\author{
Haruya Miyazawa $^{1}$, Motohiko Sano ${ }^{1}$, Uwe Fischer ${ }^{2}$, Goshi Kato ${ }^{1 \S}$ \\ ${ }^{1}$ Tokyo University of Marine Science and Technology, Konan 4-5-7, Minato-ku, Tokyo, \\ 108-8477, Japan \\ ${ }^{2}$ Friedrich-Loeffler-Institut, Südufer 10, Greifswald-Insel Riems, 17493, Germany
}

\begin{abstract}
Bath-immunization is a desirable vaccination method for fish, especially for those where injection vaccination is not available due to their small size. It has been shown previously that Aeromonas salmonicida subsp. salmonicida (A.s.s.) as well as Yersinia ruckeri and Vibrio anguillarum bacterins are taken up by rainbow trout and Japanese flounder gill epithelial cells which have been designated antigen sampling cell. In this study, we investigated the antigen uptake of several bacterins during bath-vaccination in ayu for which injection vaccination is not available, compared with those in rainbow trout.

A.s.s. , Streptococcus iniae and Flavobacterium psychrophilum were cultured in broth and inactivated with $0.3 \%$ formalin. Ayu (approx. $20 \mathrm{~g}$ ) and rainbow trout (approx. $10 \mathrm{~g}$ ) were then bath-vaccinated with each bacterin, at a concentration of $10^{6} \mathrm{CFU} / \mathrm{ml}$ and the gills were collected into Davidson's fixative. Fish treated with medium were used as negative controls. Paraffin-embedded sections of the gills were immunohistochemically stained with rabbit serum against the corresponding bacterial species and a secondary antibody conjugated with horse radish peroxidase.

As reported in rainbow trout, A.s.s. bacterin were taken up by the gill epithelium of ayu. The uptake were observed at the secondary lamellae and its basement. In contrast to the result of A.s.s bacterin, no signals were recorded in the gill epithelium in immunohistochemistry neither in ayu nor in rainbow trout after bath exposure to $S$. iniae bacterin. F. psychrophilum bacterin was taken up by the lamellar gill epithelium of ayu, whereas no signals were observed in rainbow trout gill epithelium. These data suggest that ayu also has antigen sampling cells in the gill epithelium and bacterin uptake depends on the kind of bacterium and the fish species.
\end{abstract}

\section{KEYWORDS}

bath-vaccination, gills, antigen sampling cells, rainbow trout, ayu

$\S$ Corresponding author. Tel: +81-3-5463-0462

E-mail address: gkato00@kaiyodai.ac.jp 